\title{
Science and Rhetoric: From Giordano Bruno's Cena de le Ceneri to Galileo's Dialogue on the Two Chief World Systems
}

\author{
Ingrid D. Rowland
}

The year 1610, as Floris Cohen has noted, marked a signal moment in the history of science. ${ }^{1}$ In that year, Galileo Galilei, Professor of Mathematics at the University of Padua, announced his discoveries with the telescope, including the craters of the Moon, several clouds of stars, and the moons of Jupiter, in a book he called the Sidereus nuncius ('The Starry Messenger'). ${ }^{2}$ He wrote in a limpid Latin to reach an international community of readers; such was the importance of his message. The book was published in Venice, not only because Venice was the center of Italy's printing industry, but also because Galileo's home institution, the University of Padua, was that city's de facto university, chartered by the Venetian Republic rather than a Pope or a monarch. ${ }^{3}$ The title page of the Starry Messenger reveals, however, that Galileo harbored ulterior plans for his own career, for it records the fact that he has named the moons of Jupiter the Medicean Stars, paying homage to the sons of Cosimo II de' Medici, the Grand Duke of Tuscany. ${ }^{4}$ A Tuscan himself and a restless soul by nature, Galileo was hoping for an appointment to the University of Pisa, at a much higher salary and with greater prestige than Padua was willing to provide. The naming of the stars may have played a smaller role than the magnitude of Galileo's achievement in furthering his career, but he was certainly summoned shortly thereafter to join the faculty at Pisa, the shining star in that university's academic firmament. ${ }^{5}$

In early seventeenth-century Tuscany, the language of choice, from lofty diplomatic correspondence to exchanges on the street, was Tuscan vernacular. Galileo, of course, would feel perfectly at home; other professors, like Paganino Gaudenzio, born in an Alpine valley of what is now Switzerland, were put at

1 Floris Cohen, in this volume, esp. p. $15^{0 .}$

2 Galileo Galilei, Sidereus nuncius, 1610.

3 Grendler, The Universities of the Italian Renaissance, pp. 21-40.

4 Biagioli, Galileo Courtier, passim.

5 A classic account in Cochrane, Florence in the Forgotten Centuries, pp. 165-80. 
a distinct disadvantage, and Gaudenzio, at least, would continue to publish in Latin. ${ }^{6}$ For Galileo, with his international stature guaranteed, writing in Tuscan was a luxury he could easily permit himself. Ever since the fifteenth century, patriotic Tuscans had enjoyed drawing an invidious contrast between their Etruscan tradition of small independent city-states and the iron fist of Imperial Rome. ${ }^{7}$ From the halls of the Vatican, in turn, Lorenzo Valla launched eloquent invectives against that 'Etruscan shit' Poggio Bracciolini. By the midsixteenth century, a whole school of thought had developed in Tuscany that traced local volgare directly back to the language of Etruria, despite the fact that every effort to read surviving Etruscan inscriptions had fallen short of total—or even minor—success. ${ }^{8}$ With implicit faith, these Tuscan loyalists believed that there was no nuance of human experience, no arcane technical, legal, or theological term, no glimmer of poetry for which the volgare of Dante and Petrarch could not match or surpass Latin; never mind that Grand Duke Cosimo I and his successors were not exactly republican freedom fighters in the grand Etruscan tradition, or that various members of that Florentine dynasty had come down as brutally on Volterra and Siena as any Roman legion ever came down on a barbarian horde. ${ }^{9}$

From Pisa, accordingly, and with great gusto, Galileo would write in vernacular, from his work on floating bodies, Il Saggiatore ('The Assayer', 1622), to his supremely ambitious Dialogue on the Two Chief World Systems of 1632. Floris Cohen has shown how Galileo's Two New Sciences of 1638 incorporates Latin material written during his time in Padua into a dialogue written in Tuscan. ${ }^{10}$

Galileo's choice to write in Tuscan flattered not only the Grand Duke. The papal conclave of 1623 crowned the Tuscan prelate Maffeo Barberini as Urban VIII. The new pope had been born outside Florence in the little town of Barberino Val d'Elsa, with a coat of arms that bore three horseflies, tafani; the family name was, in fact, Barberini de' Tafani. At a certain point in his career, the ambitious Maffeo decided that his heraldic horseflies might eventually

6 Cochrane, Tradition and Enlightenment in the Tuscan Academies; Idem, Florence in the Forgotten Centuries, passim; Cipriani, Il mito etrusco; Rowland, The Scarith of Scornello, pp. $67-69$.

7 Cipriani, Il mito etrusco.

8 Cipriani, Il mito etrusco.

9 For the siege of Volterra, see Fiumi, L'impresa di Lorenzo de'Medici contro Volterra. For the siege of Siena, see Cantagalli, La guerra di Siena.

10 Cohen, in this volume, pp. 150-51. 
prove an embarrassment, and he changed them to busy bees. ${ }^{11}$ The rest is history, and we shall return to that history in a moment.

First, however, it is important to note that Galileo's Starry Messenger, the book that brought him back to Tuscany, was as innovative in its form as in its content. Galileo presented his observations in pictures as well as words, in a series of exceptionally fine engraved plates taken from his own ink wash drawings. It is hard to believe, from his remarkable portraits of the Moon's pockmarked face, that the great astronomer was already plagued by serious problems with his eyesight and that he would eventually go blind in his old age. His views of ridges and crater are strikingly clear, and so are his records of the moons circling Jupiter, those Medicean satellites orbiting around the king of the gods as Leopoldo and Ferdinando de' Medici were presumed to orbit around their father, the Grand Duke. Galileo also drew what he called cloudy areas, nebulose; modern astronomers, following his lead, still call these formations nebulas. ${ }^{12}$

Most wonderful of all is his woodcut of the Pleiades, the star cluster that traditionally numbered six, although my father, who had exceptional vision until he was nearly eighty, could see nine Pleiades for most of his life. But Galileo's telescope revealed a multitude, a plethora of Pleiades, a Greek name that means 'more' or 'many'. In the Starry Messenger, Galileo shows a veritable starburst of Pleiades, and some copies of the volume, though by no means all, print the page so that the stars of this newly expanded universe burst the margins of the text block. It is a marvelously evocative image of the way in which Galileo's observations were beginning break through the boundaries of traditional cosmology.

Despite the fact that Galileo called himself a mathematician and his endeavor natural philosophy, there has been little doubt since 1610 that what he reported in the Starry Messenger was what would eventually be called science, a new science, to borrow the description he would use of his own researches in $1638 . .^{13}$ And yet, as Johannes Kepler noted in a letter he wrote to Galileo in 1610 , in his first excitement at reading the Starry Messenger, not everything that Galileo had done was new, including aspects of his new science. The telescope,

\footnotetext{
11 Cole, 'Cultural Clientelism and Brokerage Networks', p. 732.

12 Galileo's illustrations have recently become the focus of controversy: see Stefano Gattei, review of Horst Bredekamp (ed.), Galileo's O, Nuncius Newsletter, 6, December 10, 2012, http://www.museogalileo.it/en/newsletterslist/nunciusnewsletter_06_2012_eng/book_ reviews_06_2012.html (consulted July 28, 2014).

13 For this issue, see Cohen, The Scientific Revolution.
} 
Kepler suggested, was a tool; the real challenge for natural philosophy was to pose the right questions before letting the tools do their work. ${ }^{14}$

Certe qui rerum causas, antequàm res patent sensibus, concipiunt ingenio, ii Architecti similiores sunt caeteris, qui post rem visam cogitant de causis. Itaque non invidebis Galilaee nostris antecessoribus suam his laudem [...] Sic tu hanc Brutii nostri ex Bruno mutatam doctrinam emendas.

Certainly those of us who can conceive the causes of phenomena in their minds before the phenomena are revealed are more like Architects than the rest of us, who consider causes only after they have seen the phenomena. Do not, therefore, Galileo, begrudge our predecessors their proper credit.... You refine a doctrine borrowed from Bruno.

As Floris Cohen stated, Kepler was well on the way to hypothetical method rather than the traditional speculative method of natural philosophy. ${ }^{15}$ In Cohen's terms, Kepler speaks from the speculative tradition when he admonishes Galileo, in his letter of 1610 , that posing a well-conceived thought problem is a means of seeing into the mind of God, whereas empirical research is the work of mortals. Furthermore, Kepler singles out for inclusion among these godlike thinkers an older contemporary of Galileo, the southern Italian philosopher Giordano Bruno, burned at the stake in Rome on February 17, 1600 , less than a decade before Galileo took up his telescope.

Now anyone who has tried to fix a simple telescope on the heavens knows that Galileo was an observer of phenomenal perspicacity. His hand must have been uncannily steady — but we know that already from his drawings of what he saw through his eyepiece. His visual memory and his patience must have been no less extraordinary. The discipline that kept him staring at the heavens night after night was that of an Early Christian anchorite. The Starry Messenger deserves every bit of its reputation as a foundational document of modern science.

Giordano Bruno, on the other hand, has largely fallen out of this history of science, for a number of reasons, which include his choices of the language in which to present his ideas. Prevailing scholarly opinion in the Englishand Italian-speaking worlds holds him as that odd creature, 'the Renaissance magus', and attempts to bring him into the history of natural philosophy—let

\footnotetext{
14 Kepler, Dissertatio cum nuncio sidereo, 1610, p. 10 .

15 Cohen, in this volume, p. 149.
} 
alone the history of science, meet occasional accusations of trying to read the future into the past. ${ }^{16}$ To a certain extent this interpretation of Bruno belongs to a particular generation - of Frances Yates and her students in the Englishspeaking sphere, of Paolo Rossi, Paola Zambelli and their students in the Italian. ${ }^{17}$ Bruno himself usually claimed to be a philosopher (and occasionally a professor of theology), not a magus, and certainly never a Renaissance magus. ${ }^{18} \mathrm{He}$ called his philosophy a 'natural and physical discourse'. ${ }^{19}$ On these data, and on Kepler's assessment in his letter to Galileo I rest my own case for treating Giordano Bruno as a natural philosopher, a part of, not apart from, a large, variegated philosophical community whose members, from Paracelsus to Newton, frequently carried out researches in the fields of magic and alchemy.

And then, Bruno's linguistic choices, including the visual language of his published books, have also conspired to keep him outside the conventional fast track that leads from Leonardo to Kepler to Galileo. Unlike Galileo, he normally published on the cheap because he had to. His books are tiny little things, often poorly printed and riddled with errors, to which he often made his own corrections by hand as the pages emerged from the press. ${ }^{20}$ We can see such corrections in his first known publication as a natural philosopher, the Ash Wednesday Supper of 1584. The book lacks an imprint, but in fact the printer is John Charlewood of London, who would give false Parisian imprints for Bruno's subsequent books. ${ }^{21}$ These false imprints may have been an attempt to give the works some continental panache, or bella figura, at a time when continental panache meant a great deal, for in 1584, Elizabethan England was feeling its way into becoming a great international power. Philip II was already

16 So, especially, Yates, who put the phrase 'the Renaissance magus' into circulation. See, e.g., Yates, Giordano Bruno and the Hermetic Tradition, p. 168: 'In short, it was as a Ficinian Magus that Bruno presented himself at Oxford'; ibid. 'he was a Hermetic Magus of a most extreme kind with a magico-religious mission of which Copernicanism was a symbol'.

17 Yates, The Art of Memory; Eadem, Giordano Bruno and the Hermetic Tradition; Walker, Spiritual and Demonic Magic from Ficino to Campanella; Rossi, Clavis Universalis; Zambelli, White Magic, Black Magic in the European Renaissance, pp. 218-53.

18 Gatti, Giordano Bruno and Renaissance Science, p. 18: 'During the grueling questioning he underwent at the hands of the Inquisition in the long years of his trial, Bruno consistently defined himself as a philosopher. Such a definition formed an essential part of his defense.'

19 Giordano Bruno, De gli Heroici Furori, letter of dedication, Italian text translated from Bruno, Dialoghi Italiani, ed. Gentile, rev. Aquilecchia, II, pp. 932-33.

20 Rita Sturlese, introduction to Bruno, De umbris idearum, ed. Sturlese.

21 Provvidera, 'John Charlewood, Printer of Giordano Bruno's Italian Dialogues', Gatti, Giordano Bruno, Philosopher of the Renaissance, pp. 167-86. 
assembling the fleet that would become his Invincible Armada, flung against the Royal Navy in 1588 and routed by the rebellious elements of a perfect North Atlantic storm. ${ }^{22}$ Elizabeth herself, literate in Greek and Latin, could converse easily in French, Spanish, and Italian. ${ }^{23}$ So could the most sophisticated members of her court, and it is to this cosmopolitan urban crowd that Giordano Bruno aimed his natural and physical discourse in his native vernacular, the pungent volgare of Naples.

Bruno had left Naples in 1576, and came to London from Paris in the spring of 1584. In France he had forged a personal relationship with King Henry III, but increasing tensions between Catholics and Protestants made the position of a man with Bruno's history a dangerous one: he had been defrocked as a Dominican in Naples, and excommunicated as a Catholic, but he had also been excommunicated by the Calvinists in Geneva. ${ }^{24} \mathrm{He}$ came to London in the entourage of the French Ambassador to the Court of St. James, and hoped at first to find a professor's post at Oxford. His letter of application, written in Latin, was enough to earn him an invitation, but it was unusual, to say the least:

Philotheus Iordanus Brunus Nolanus magis elaboratae theologiae doctor, purioris et innocuae sapientiae professor, in praecipuis Europae academiis notus, probatus et honorifice exceptus philosophus, nullibi praeterquam apud barbaros et ignobiles peregrinus, dormitantium animorum excubitor, praesumptuosae et recalcitrantis ignorantiae domitor, qui in actibus universis generalem philanthropiam protestatur, qui non magis Italum quam Britannum, marem quam feminam, mitratum quam coronatum, togatum quam armatum, cucullatum hominem quam sine cuculla virum, sed illum cuius pacatior, civilior, fidelior et utilior est conversatio diligit, qui non ad perunctum caput, signatum frontem, ablutas manus et circumcisum penem, sed (ubi veri hominis faciem licet intueri) ad animum ingeniique culturam maxime respicit, quem stultitiae propagatores et hypocritiunculi detestantur, quem probi et studiosi diligunt, et cui nobiliora plaudunt ingenia, excellentissimo clarissimoque Oxoniensis academiae procancellario, una cum praecipuis eiusdem universitatis, salutem plurimam dicit.

22 Invincible armada's defeat and weather's role in it. Fagan, The Little Ice Age, pp. 80, 90-96.

23 References collected in Spampanato, Vita di Giordano Bruno (1921), with an afterword by Ordine, pp. 347-48. See also Mueller and Scodel, Elizabeth I.

24 Latin text from Tocco and Vitelli, Iordani Bruni Nolani Opera Latine Conscripta, vol. II, 2, pp. 76-78; English translation from Rowland, Giordano Bruno, Philosopher/Heretic, pp. 114, 225 . 
Philotheus Jordanus Brunus Nolanus, doctor of a more sophisticated theology, professor of a more pure and innocent wisdom, known to the best academies of Europe, a proven and honored philosopher, a stranger only among barbarians and knaves, the awakener of sleeping spirits, the tamer of presumptuous and stubborn ignorance, who professes a general love of humanity in all his actions, who prefers as company neither Briton nor Italian, male nor female, bishop nor king, robe nor armor, friar nor layman, but only those whose conversation is more peaceable, more civil, more faithful and more valuable, who respects not the anointed head, the signed forehead, the washed hands or the circumcised penis, but rather the spirit and culture of mind (which can be read in the face of a real person); whom the propagators of stupidity and the small-time hypocrites detest, whom the sober and studious love, and whom the most noble minds acclaim, to the most excellent and illustrious vice-Chancellor of the University of Oxford, many greetings.

The letter ended no less graphically:

Interim nolim ut quemadmodum tempore diluvii asinorum stercora malis aureis dixerunt 'Nos quoque poma natamus', ita nunc cuilibet stulto et asino liceat in nostras positiones hic vel alibi, hoc vel alio modo prolatas obrudere; sed si qui eius sunt tituli, dignitatis vel sufficientiae, ut nostro congressu aliqua ratione non habeantur indigni, et quibus sine conditionis nostrae dedecore respondere possimus, hominem promptissimum et paratissimum, per quem pondus suarum valeant experiri, comperient. Valete.

In the meantime I would not want it to come to pass, as in the days of the Flood, when the asses' dung said to the golden apples, 'We [road] apples can swim too', that now, too, any stupid ass might bray against the positions we have put forth here or elsewhere, in this or that way but if there be anyone whose claims to stature and qualification will not be held for any reason as unworthy of our company, and to whom we can respond without any detriment to our condition, they shall find me a man prompt and prepared, for whom it may be worthwhile to test the weight of their own [positions]. Farewell. ${ }^{25}$ 
He also lectured, needless to say, in Latin, the Latin he had refined at the Dominican College of Naples, the single most exclusive university in southern Italy, at a time when southern Italy was an ample kingdom under a Spanish viceroy, and Naples ranked with London and Paris among the most populous cities in the world. Elizabethan Oxford had a faculty with humanistic inclinations, yet Bruno, despite his own passionate immersion in the Neapolitan version of Marsilio Ficino's Neoplatonism, managed to alienate them all. In the first place, he spoke Latin with an Italian accent. George Abbott, a future Archbishop of Canterbury who was then a student, reported in his pungent Elizabethan English that:

When he had more boldly than wisely, got up into the highest place of our best and most renowned schoole, stripping up his sleeves like some Iugler, and telling us much of chentrum and chirculus and cirumferenchia (after the pronunciation of his Country language) he undertooke among very many other matters to set on foote the opinion of Copernicus, that the earth did goe round, and the heavens did stand still; whereas in truth it was his owne head which rather did run round, and his braines did not stand stil. ${ }^{26}$

Secondly, Bruno's powers of recall were so acute that when he cited Ficino from memory he brought forth such extensive passages that the dons accused him of plagiarism. Again Abbott is our source:

When he had read his first Lecture, a grave man, and both then and now of good place in that University, seemed to himselfe, some where to have read those things which the Doctor propounded; but silencing his conceit till he heard him the second time, remembered himselfe then, and repayring to his study, found both the former and later Lecture, taken almost verbatim out of the worke of Marsilius Ficinus. Wherewith when he had acquainted that rare and excellent Ornament of our land, the Reverend Bishop of Durham that now is, but then Deane of ChristsChurch, it was a the first thought fit, to notifie to the Illustrious Reader, so much as they had discovered. But afterward hee who gave the first light, did most wisely intreate, that once more they might make trial of him; and if he persevered to abuse himselfe, and that Auditory the thirde time, they shoulde then do their pleasure. After which, Iordanus continuing to be idem Iordanus, thay caused some to make knowne unto him their 
former patience, and the paines which he had taken with them, and so with great honesty of the little man's part, there was an end of that matter. ${ }^{27}$

Thirdly, as good humanists and good Neoplatonists, they held their own high regard for the first great Neoplatonist, Aristotle of Stagira-and, as George Abbot makes clear, when the little Italian began to talk about Copernicus they were having none of it.

Furthermore, Bruno not only gave his Latin a laughable pronunciation to English ears. When he was not quoting Ficino, he used a Latin honed to fine precision in the very halls where Thomas Aquinas had once held forth; it was as perfectly Scholastic, and therefore as drily medieval, as old-fashioned, as steeped in Popery, as Latin could be. In short, Bruno professed radically new ideas in the most archaic lingua franca that united Elizabethan England to the rest of Europe, and he was a foreigner, a little, comical foreigner who gesticulated as only Italians could and flew into comical little Italian rages when he failed to get his point across.

In London, on the other hand, and at court, things Italian were the height of fashion. Bruno's housemate John Florio, then serving as tutor to the French ambassador's daughter, would compose Britain's first Italian-English dictionary, the World of Words, and a young playwright named Shakespeare set his dramas in Rome, Verona and Venice because those names sounded as romantic to his public as Tuscany does to a present-day Californian. ${ }^{28}$

And so, having failed to communicate Copernicus by the hard logic of Scholastic syllogism, Giordano Bruno turned to the most humanistic, the most Platonic of media, the philosophical dialogue, and couched that dialogue in the language he commanded best: the ripe, ribald vernacular of Naples, ranging across its registers with a pen as sharp as his ear.

He began the Ash Wednesday Supper with an assault on his critics:

Se da Cinico dente sei trafitto,

Lamentati di te barbaro perro:

Ch'in van mi mostri il tuo baston, et ferro:

Se non ti guardi da farmi despitto.

27 Aquilecchia, 'Giordano Bruno in Inghilterra', p. 34.

28 Wyatt, The Italian Encounter with Tudor England; Gatti, The Renaissance Drama of Knowledge; Ciliberto and Mann, Giordano Bruno, 1583-1585. 
Per che col torto mi venesti à dritto, Pero tua pelle straccio, et ti disserro:

Et s'indi accade ch'il mio corpo atterro, Tuo vituperio è nel diamante scritto.

Non andar nudo à torre à l'api il mele.

Non morder se non sai s' è pietra, ò pane.

Non gir discalzo à seminar le spine.

Non spreggiar mosca d'aragne le tele.

Se sorce sei, non sequitar le rane,

Fugge le volpi, ò sangue di galline.

Et credi à l' Euangelo,

Che dice di buon zelo,

Dal nostro campo miete penitenza:

Chi vi gittò d'errori la semenza.

If you've been worried in a cynic's bite

You brought it on yourself, you barbarous cur

In showing me your weaponry you err

Unless you're careful not to rouse my spite.

The frontal charge you made was hardly right; I'll shred your hide and pull out all your fur, And if I hit the ground, you'll still concur:

Like diamond, I repel the taunts you write.

Don't rob a hive of honey in the nude

Don't bite unless you know it's stone or bread

Don't scatter thorns unless you're wearing shoes

On spiderwebs a fly should not intrude

A rat that follows frogs is good as dead.

Hens and their brood all foxes should refuse

And trust the Gospel verse

That tells you, kind and terse:

For him who sows a field with errors and lies

A harvest of regret shall be the prize. ${ }^{29}$

Giordano Bruno, Cena de le Ceneri, Italian text from Dialoghi Italiani, I, p. 5. 
The dialogue proper opens, like Plato's, in medias res, but its tone is scathing:

SMi: Parlavan ben latino? The: Si. Smi: Galant'huomini? The: Si. SMI: Di buona riputatione? ThE: Si. SMI: Dotti? ThE: Assai competentemente. SMI: Ben creati, cortesi, civili? ThE: Troppo mediocremene. SMI: Dottori? The: Messer si, Padre si, Madonnasi, Madesi; credo da Oxonia. Sm I: qualificati? THE: Come non? Huomini da scelta, di robba lunga, vestiti di velluto; un de quali havea due cathene d'oro lucente al collo: et l'altro (per Dio) con quella pretiosa mano (che contenea dodeci anella in due dita) sembrava uno ricchissimo gioielliero, che ti cavava gl' occhi et il core, quando la vagheggiava. SMI: mostrauano saper di greco? THE: Et di birra etiam dio.

Smitho: Did they speak good Latin?

Teofilo: Yes.

S: Gentlemen?

T:Yes.

S: Of good reputation?

T:Yes.

S: Learned?

T: Most competently.

S: Well bred, courteous, civil?

T: Not enough.

S: Doctors?

T: Yes Sir, yes, Father, yes Ma'am, yes indeed; from Oxford, I believe.

S: Qualified?

T: Of course. Leading men, of flowing robes, dressed in velvet; one of whom had two shiny gold chains around his neck, the other, by God! with that precious hand (that contained twelve rings on two fingers) he looked like a rich jeweler; your eyes and heart popped out just looking at it.

S: Were they steeped in Greek?

T: And in beer, too, forsooth. ${ }^{30}$

The Ash Wednesday Supper is, among its many other qualities, extremely funny, clearly inspired by the tragicomedy of Plato's Symposium, which he pointedly evokes in the letter that dedicated this work to his London host, the Ambassador, Michel de Castelnau.

3o Ibidem, I, pp. 20-21. 
Sleek Londoners could laugh at his portrayal of Oxford dons: a contemporary scholar lamented the same contrast between his professorial robes and the silks of the nobility:

When once in black I disrespected walked,

While glittering courtiers in their tissues stalked. ${ }^{31}$

In the event, however, the Ash Wednesday Supper ensured that Giordano Bruno would have no future in England. His stiletto was too sharp, and it only became sharper as he composed four more vernacular dialogues about his natural philosophy. He had concluded that neither Aristotle nor Copernicus understood the true nature of the cosmos: it was not one closed system of concentric spheres orbiting within a sphere of fixed stars, but an infinite series of orbital systems ranging free in an infinite expanse of space. Our place in that infinitude was thus infinitely tiny, but that very tininess was more than compensated by the immensity of the ideas an infinitely expanded cosmos made available to an unfettered mind. ${ }^{32}$

This lifting of every intellectual limit was the freedom that Bruno believed his philosophy could offer to the world, and in the Ash Wednesday Supper he let no courtly modesty stop the impassioned charge of his self-congratulation:

Il Nolano ... ha disciolto l'animo umano e la cognizione, che era rinchiusa ne l'artissimo carcere de l'aria turbolento; onde a pena, come per certi buchi, avea facultà de remirar le lontanissime stelle, e gli erano mozze le ali, a fin che non volasse ad aprir il velame di queste nuvole e veder quello che veramente là su si trovasse... Or ecco quello, ch' ha varcato l'aria, penetrato il cielo, discorse le stelle, trapassati gli margini del mondo, fatte avanire le fantastiche muraglia de le prime, ottave, none, decime ed altre, che vi s'avesser potuto aggiongere, sfere, per relazione de vani matematici e cieco veder di filosofi volgari; cossì al cospetto d'ogni senso e raggione, co' la chiave di solertissima inquisizione aperti que' chiostri de la verità, che da noi aprir si posseano, nudata la ricoperta e velata natura, ha

31 Thomas Randolph, first Earl of Moray, 'On a maide of honor seene by a scholler in Sommerset Garden', in Gardner, The Metaphysical Poets, p. 16o: 'As once in blacke I disrespected walk't, / Where glittering courtiers in their tissues stalk't, / I cast by chaunce my melancholy eye, / Upon a woman (as I thought) pass'd by. / But when I veiw'd her ruffe and beaver reard / As if Priapus-like she would have feard, / The ravenous Harpyes from the clustred grape, / Then I began much to mistrust her shape [...].' 
donati gli occhi a le talpe, illuminati i ciechi che non possean fissar gli occhi a mirar l'imagin sua in tanti specchi che da ogni lato gli s'opponeno, sciolta la lingua a' muti che non sapeano e non ardivano esplicar gl'intricati sentimenti, risaldati i zoppi che non valean far quel progresso col spirto che non può far l'ignobile e dissolubile composto, le rende non men presenti che si fussero proprii abitatori del sole, de la luna ed altri nomati astri... Questi fiammeggianti corpi sono que' ambasciatori, che annunciano l'eccellenza de la gloria e maestà de Dio. Cossí siamo promossi a scuoprire l'infinito effetto dell'infinita causa, il vero e vivo vestigio de l'infinito vigore; ed abbiamo dottrina di non cercar la divinità rimossa da noi, se l'abbiamo appresso, anzi di dentro, piú che noi medesmi siamo dentro a noi.

The Nolan... has released the human spirit and intellect, which were confined in the narrow prison of the turbulent atmosphere; whence they scarcely had the capacity to look, as through certain holes, upon the distant stars, and whose wings were clipped, so that they could not fly through the veil of these clouds and see what is really to be found above... Now behold him, who has crossed the air, penetrated the heavens, wandered among the stars, and passed beyond the margins of this world, made to vanish the imaginary walls of the first, eighth, ninth, tenth and as many other spheres as you would like to add, according to the reports of vain astronomers and the blind visions of vulgar philosophers; [who] thus, in the presence of all sense and reason, with the key of clever investigation has opened those cloisters of the truth, that can be opened by us, stripped naked the covered and veiled truth, given eyes to moles, enlightened the blind who could not focus their eyes to admire their own image in these many mirrors appearing on every side, loosened the tongue of the mute who could not and dared not express their innermost feelings, healed the lame who could not make that progress with their spirits that our ignoble and dissolute flesh cannot make, and makes them no less present than if they were dwellers on the Sun, the Moon, and the other known stars... These flaming bodies are the ambassadors who proclaim the glory and majesty of God. Thus we are moved to discover the infinite effect of the infinite cause, the true and living footprint of the infinite vigor, and we have a teaching that tells us not to seek divinity outside ourselves, but within, more deeply in us than we are ourselves. $^{33}$ 
The Ash Wednesday Supper had a few diagrammatic illustrations, one notoriously inaccurate. ${ }^{34}$ Some of his previous works on memory had used emblematic images as student exercises. In his sixth and final vernacular dialogue, $O n$ the Heroic Frenzies, he tried to combine natural philosophy with ethics, using sonnets, songs, and emblems to convey his ideas. The 28 emblems of the Heroic Frenzies were described rather than illustrated, but they clearly drew from contemporary emblematic literature, and one of the images may well be inspired by Titian's allegorical painting of Prudence, now in London, at that time in Venice. ${ }^{35}$ This is the sonnet that accompanies an image he explains not as prudence, but as the confused head of an anguished lover, albeit not an erotic lover, but rather a lover of wisdom, a philosopher eager for truth:

Un alan, un leon, un can appare

a l'auror, al dì chiar, al vespr'oscuro.

Quel che spesi, ritegno, e mi procuro, per quanto mi si die', si dà, può dare.

Per quel che feci, faccio et ho da fare al passat', al presente et al futuro, mi pento, mi tormento, m'assicuro, nel perso, nel soffrir, nell'aspettare.

Con l'agro, con l'amaro, con il dolce l'esperienza, i frutti, la speranza mi minacciò, m’affligono, mi molce.

L'età che vissi, che vivo, ch'avanza mi fa tremante, mi scuote, mi folce, in absenza, presenza, e lontananza.

Assai, troppo, a bastanza quel di già, quel di ora, quel d'appresso m'hann' in timor, martir, e spene messo.

A wolf, a lion, and a dog shall show At dawn, at bright of day, at evening's gloom; What I gave out, possess, and shall assume, This much was given me, gives, shall bestow. 
For what I did, I do, my next creation

Before, at present, and in days ahead

I rue, torment myself, assuage my dread

In loss, in suffering, in expectation.

And with the sour, the bitter, and the sweet

Experience, the fruits, expectancy

Scared me, afflict me, makes my cares retreat

The span I lived, live, what remains to me

Sets me aquiver, shakes me, guides my feet

In absence, presence, and in scarcity.

Greatly, too much, sufficiently

What happened then, what now, and what comes next

Keep me in fear, distress, and hope perplexed. ${ }^{36}$

This is all a far cry from Galileo's pictures of the Moon, and considerably less distant, I would argue, from Galileo's image of the Pleiades. But another image from Bruno will take us still closer to Galileo.

The Italian philosopher's sojourn in London ended with the recall of his host in 1585; they both returned to Paris, where the language of urban sophisticates, needless to say, was French. Bruno surely spoke French, but he never wrote in that language; by sheer atavistic instinct it would have been hard for a sixteenth century Italian, heir to the Roman Empire, to exchange that illustrious tongue for the accents of Transalpine Gaul. He wrote instead in Latin, still favoring dialogue as his medium (and would continue to write in Latin when his journeys took him to German-speaking lands). This second Parisian stay ended as things always ended for Bruno: in a fight. At the time, Paris was much taken with the work of a mathematician from Salerno, Fabrizio Mordente, who had invented a compass that, he claimed, allowed him to solve the age-old geometric problem of squaring the circle, that is, producing a square whose perimeter exactly equalled the circumference of a given circle. This is easily done with string; the challenge was to do it by using compass and straightedge. Mordente's trick was to give the compass adjustable legs. He was basically a technician, an instrument maker, and decidedly a man of the working class, for he knew no Latin. Bruno, as a fellow southern Italian, offered to translate

36 Italian and English texts from Bruno, De gli Heroici Furori, ed. Canone, transl. Rowland, pp. 210-11. 
Mordente's own essay on his compass into Latin in order to give it greater prestige.

Bruno was not Mordente's only learned acquaintance, however, and hence it was only a matter of time before Mordente discovered that the hero of the pamphlet called Mordente's Compass was not Mordente himself but his brilliant friend Giordano, the genius who truly grasped the instrument's potential. No one grew any more calm when Bruno fired off another Latin pamphlet, Idiota Triumphans: even Mordente could see who was meant to be the 'triumphant idiot' of the title. ${ }^{37}$

But as usual, Bruno was indeed thinking, as Kepler would observe, with a creator's outlook. A little woodcut from Mordente's Compass shows the direction in which his ideas are pointing. Once he had resolved that the universe was infinite, he began to wonder how objects moved within it - the old Aristotelian distinction between circular and linear motion no longer applied to this new setting. To this end, Bruno began to concentrate his attention on how a straight line comes to approximate a curve and vice versa. Squaring the circle was perhaps the archetypal example of this transformation. Though Bruno discovered fairly quickly that Mordente's compass would not solve that particular problem, he retained his interest both in the instrument itself and in the more basic issue at hand, which was that of approximation: how a straight line gradually verges into a curve, how motion verges into rest, how a three-dimensional surface verges into a two-dimensional plane. He was moving, tentatively and with what would prove to be the wrong set of tools, towards the infinitesimal calculus. ${ }^{38}$ The very term 'calculus' suggests where the solution to this problem would lie: in numbers, considered algebraically, something Bruno never did — with regard to numbers, he remained a numerologist. ${ }^{39}$ But he was, as some of his diagrams reveal, as uninhibited a thinker as the sixteenth century produced.

Galileo would address the problem of motion in his Two New Sciences, but from a radically different standpoint from that of Bruno, a standpoint first expressed in his polemic against the Jesuit Orazio Grassi, Il Saggiatore:

e forse stima, che la Filosofia sia un libro, e una fantasia d'un uomo, come l'Iliade, e l'Orlando furioso, libri ne' quali la meno importante cosa è, che quello che vi è scritto, sia vero. S. Sarsi la cosa non istà così. La Filosofia è scritta in questo grandissimo libro, che continuamente ci stà aperto

37 De Bernart, Numerus quodammodo infinitus.

38 Rowland, 'Giordano Bruno e la geometria dell'infinitamente piccolo'.

39 Gatti, Giordano Bruno and Renaissance Science, pp. 143-70. 
innanzi a gli occhi (io dico l'universo) ma non si può intendere se prima non s'impara à intender la lingua, e conoscer i caratteri, ne' quali è scritto. Egli è scritto in lingua matematica, e i caratteri son triangoli, cerchi, \& altre figure Geometriche, senza i quali mezi è impossibile à intendere umanamente parola; senza questi è un'aggirarsi vanamente per un'oscuro laberinto.

Perhaps [my adversary] thinks that Philosophy is a book, and [the product of] one man's imaginings, like the Iliad, and Orlando Furioso, books in which the least important matter is whether the contents are true. Signor Sarsi, it's not like that. Philosophy is written in this great book that stands continually open before our eyes (I mean the universe), but you cannot understand it until you learn to understand its language, and know the script in which it is written. It is written in the language of mathematics, and the letters are triangles, circles, and other Geometric figures, and without these means it is impossible for a person to understand one word; [to be] without them is to wander vainly through a dark labyrinth. ${ }^{40}$

Or are their outlooks that different? Galileo could have written what Bruno says about his choice to write in vernacular in another of his London dialogues, Expulsion of the Triumphant Beast:

Qua Giordano parla per volgare, nomina liberamente ... chiama il pane, pane; il vino, vino; il capo, capo; il piede, piede; ed altre parti, di proprio nome; dice il mangiare, mangiare; il dormire, dormire; il bere, bere ... Ha gli miracoli per miracoli, le prodezze e maraviglie per prodezze e maraviglie, la verità per verità, la dottrina per dottrina, la bontà e virtú per bontà e virtú, gl'inganni per inganni, coltello e fuoco per coltello e fuoco, le paroli e sogni per paroli e sogni, la pace per la pace, l'amore per amore. Stima gli filosofi per filosofi, gli pedanti per pedanti, gli monachi per monachi, li ministri per ministri, li predicanti per predicanti, le sanguisughe per sanguisughe, gli disutili, montainbanco, ciarlatani, bagatellieri, barattoni, istrioni, papagalli per quel che si dicono, mostrano e sono; ha gli operarii, benefici, sapienti ed eroi per questo medesimo.

Here Giordano speaks the common language, he names names freely ... he calls bread bread, wine wine, a head a head, a foot a foot, and 
other parts by their proper name, he calls eating eating, sleeping sleeping, drinking drinking... He holds miracles as miracles, prodigies and marvels as prodigies and marvels, truth as truth, doctrine as doctrine, goodness and virtue as goodness and virtue, impostures as impostures, deceptions as deceptions, knife and fire as knife and fire, words and dreams as words and dreams, peace as peace, love as love. He regards philosophers as philosophers, pedants as pedants, monks as monks, ministers as ministers, preachers as preachers, bloodsuckers as bloodsuckers, ne'er-do-wells, mountebanks, charlatans, triflers, barterers, actors, parrots as that which they are called, show themselves to be, are; workers, benefactors, sages and heroes as themselves. ${ }^{41}$

Certainly Galileo's sharp-tongued Salviati, lampooning dull-witted Simplicio on the last page of the Dialogue on the Two Chief World Systems, committed a faux pas worthy of Giordano Bruno. His dull-witted character, Simplicio ventures an idea. To this tentative suggestion thought, Salviati says, 'A truly angelic doctrine!' before going on to refute it categorically. Unfortunately for Galileo, his source for Simplicio's idea had been none other than the Pope, Urban VIII, in one of the discussions the two were wont to have with one another, confident in their mutual high regard. Galileo placed this little piece of banter on the four hundredth page of four hundred, perhaps assuming that the Pope would not read his dialogue all the way through, or perhaps only assuming that the Pope would not see himself mirrored in Simplicio. But the Pope did read the book and did see himself in the mirror, and his wounded pride lit the fuse that exploded into Galileo's trial for heresy. ${ }^{42}$

Galileo's trial revolved more around pontifical pique than it did around science, around rhetoric rather than philosophy, and ultimately around powerthe real temporal power of the Pope and the equally real, timeless power of Galileo's pen. For both Bruno and Galileo, the pen ultimately won their battles, a pen they both wielded in two languages, but most of all in a new language all their own, made up of wit and of science.

41 Giordano Bruno, Spaccio della Bestia Trionfante, Italian text from Dialoghi Italiani, I, pp. $55^{1-52 .}$

42 This point is made most strongly by Biagioli, Galileo Courtier. 